\title{
Commercial Credit in the Activities of Business Entities: Features of Legal Regulation in the Russian Federation
}

\author{
S.V. Startseva ${ }^{1, *}$ and N.V. Deltsova ${ }^{1}$ \\ *Corresponding author: startseva-svetlana1@yandex.ru \\ ${ }^{1}$ Samara State University of Economics, Samara, Russia
}

\begin{abstract}
The activity of any economic entity, both in the Russian Federation and in any other country, needs free financial resources. They are used for entrepreneurial activities, as ultimately the purpose of such activity is to make profit. Money can be obtained under a loan agreement in a credit institution. Generally obtaining a loan from a credit institution is associated with increased costs (high bank interest and bank charges), the need to provide security and the length of the procedure for obtaining a loan. Commercial loan, however, is deprived of these shortcomings. Commercial credit is provided by economic entities to each other in the process of doing business, and it allows you to get free financial resources, both in the short and in the long business term. Economists believe that in the means of the increase of working capital a commercial loan is second in importance after banking one. Commercial loans are widespread both in the Russian Federation and abroad. Despite the widespread use of commercial credit in economic activity, it is governed by only one article in the Civil Code of the Russian Federation. The purpose of the study is to analyze a commercial loan agreement and study the legal relationship between the lender and the borrower. Objectives of the study are to study of the essence of a commercial loan; to study of the relationship of a commercial loan agreement with other agreements and other civil structures. The methods that were used in the study are the following: a formal legal method to define the concept of a commercial loan agreement, a system-structural analysis method to determine the nature of a commercial credit, a comparative legal method to determine the relationship of a commercial credit agreement to other agreements and other civil - legal constructions. The result of the study is a proven conclusion that a commercial loan agreement is an independent agreement. The findings and results of the study can be used for further research and as educational material, in legislative work and in law enforcement practice.
\end{abstract}

Keywords: commercial loan, deposit, advance, bill of exchange, contract of current account.

\section{Introduction}

The successful functioning of a market economy is based on the use of civil law obligations. Economic entities are in dire need of working capital. They are necessary to cover both current expenses and their long-term capital investments. The main sources of working capital are either credit organizations or economic entities themselves. Bank loans can not always be used by entrepreneurs in their activities due to the harsh conditions: high interest rates, unacceptable terms, unprofitable credit conditions. An alternative source of financing is a commercial loan.

\section{Problem Statement}

The Russian and foreign literature explores commercial credit. Generally these studies are of a review nature: Bychkov [1], Mikryukov [2], Gorbatov [3], Burkova [4], Braginsky \& Vitryansky [5], Chen \& Chiou [6]. The listed publications and papers do not conduct a systematic analysis of a commercial loan. Moreover, it is prudent to identify the legal aspects that arise when using a commercial loan in business activities in this study. It is also necessary to define the concept and essence of a commercial loan and compare the contract of a commercial loan with other agreements and other civil structures.

\section{Research Questions}

In the framework of this study, we will highlight the following questions:

3.1. What is the essence of a commercial loan?

3.2. How does a commercial loan agreement relate to other contracts and other civil structures? 


\section{Purpose of the Study}

The objectives of this study are: analysis of a commercial loan agreement and the study of legal relations between the lender and the borrower.

\section{Research Methods}

In the process of research many methods were used. Among them are: general scientific - analysis, synthesis, comparison, generalization; private scientific, formal legal, comparative legal, allowing to consider a commercial loan agreement, formal legal method to define the concept of a commercial loan agreement, system-structural analysis method to determine the nature of a commercial credit, comparative legal method to determine the ratio commercial loan agreement with other agreements and other civil structures.

\section{Findings}

In accordance with the Civil Code of the Russian Federation, commercial credit is a mismatch in time of the mutual fulfillment of obligations by counterparties under an agreement [7]. Traditionally, commercial lending is carried out not only in the form of a deferred payment, but also in the form of installment payment, advance payments and prepayments.

The term "credit" is widely used both in economic and legal literature in different meanings. So, economists define credit as: a loan in cash or in a commodity form; the loan deal is when the lender provides the borrower a cash amount or a deferment of payment for the goods with interest for a fixed term and on a strict repayment condition From an economic point of view, a loan is a movement of loan capital; crediting part of the accounting books, posting the amount received on credit. At the same time, the Civil Code of the Russian Federation distinguishes the concepts of a grant and a loan, in the first case it is the gratuitous use of an individually determined thing (Art. 689 of the Civil Code of the Russian Federation), in the second, it is an urgently paid use of things by certain generic characteristics (Art. 819, 822, 823 Civil Code RF).

A commercial loan is a separate sub-institution of civil law. The need to isolate it from the whole mass of credit relations is caused by the unresolved settlement of commercial loans in legislation.

There are many definitions of commercial loans in the scientific literature. A commercial loan is also often referred to as a trade loan, a supplier loan or a company loan.

The legal definition of a commercial loan agreement is enshrined in Art. 823 of the Civil Code of the Russian Federation: "Contracts whose execution involves the transfer of money or other things determined by generic characteristics to the other party may include a loan, that might be in the form of an advance, advance payment, deferment and installment payment for goods, works or services (commercial loan), unless otherwise regulated by law".

There are quite a lot of opinions about the nature of a commercial loan in legal literature; a commercial loan is understood to mean both a contractual condition, an element of paid contracts, and an element of paid civil legal relations. But at the same time, all authors unanimously state that a commercial loan agreement is not an independent agreement.

In fact, a commercial loan is not a condition in another contract, not an element of compensated contracts, and not an element of compensated civil legal relations, but an accessory contract, which is independent, but its independence is limited to the fate of the underlying contract. Parties to a commercial loan agreement can be any natural and legal persons, both engaged in entrepreneurial activities and non-business entities. The object of the relationship of a commercial loan, as indicated in Art. 823 of the Civil Code of the Russian Federation [8] may be money or generic things, but in practice there is also a commercial loan, the object of which are individually-specific things. The content of a commercial loan relationship lies in the rights and obligations of the parties that correspond to each other: the borrower has the right to receive a commercial loan - the lender must provide it, the lender has the right to repay the loan and pay for its use - the borrower must return the commercial loan and pay on his interest.

To confirm the thesis of the independent nature of a commercial loan, we compare it with other contracts and other civil structures. Analyze the similarities and differences of the deposit and advance. The advance is transferred by the borrower against future payments to the lender. Traditionally, when there is both a payment in pursuance of a deposit agreement, and a payment in pursuance of an advance agreement, they talk about their evidentiary function. The Federal'naya nalogovaya sluzhba (FNS) of Russia defines the advance as: "the funds transferred to the contractor on account of forthcoming payments under the contract between the Customer and the Contractor, for tangible assets, work performed and services rendered" [9]. In this context, the transfer of the advance will be evidence of the conclusion of the contract. Imagine a situation: even before the occurrence of the obligation, the buyer will transfer to the future seller a certain amount of money on account of the payments to be made under the agreement concluded in the future. It is unlikely that this amount can be called differently than in advance, although the evidentiary function of concluding the main contract, the sale contract, it does not fulfill, since the parties only assume the conclusion of a contract in the future, even if they agreed on some essential conditions of the future contract, evidence of the conclusion of a 
preliminary contract (Art. 429 of the Civil Code of the Russian Federation) [8].

In civil science, quite a lot of research was conducted on the possibility of using an advance along with a deposit to ensure pre-contractual liability and preliminary contracts [5]. On the basis of an analysis of the studies of civilists, it can be concluded that the advance always performs, but not as a means specified in the law, a payment function that it can perform evidentiary, but at the same time, unlike the deposit, it does not have a security function. Consequently, if the advance was transferred to the counterparty under the contractual obligation, and the obligation itself was not fulfilled or did not arise at all, then the counter agent who received the specified advance payment must return it in the same amount [10].

In our opinion, the deposit is a form of commercial credit along with advance payment, prepayment, deferment and installment payment. Everything said about the value of the deposit, as a form of a commercial loan, is confirmed by judicial practice. The deposit, named as such in the agreement of the parties, is often reclassified in advance [11]. This point of view on the nature of the advance is also reflected in the theory of civil law, so Braginsky \& Vitryansky believe that there is no reason to single out the loss of deposit as an independent measure of responsibility. he is a legal penalty (fine) [12].

Next, consider the relationship of commercial credit and bill obligations. An agreement on the granting of a commercial loan may either be included by the parties into the contract of sale and purchase (delivery contract, contract for the provision of services, etc.) initially or as changes and additions to the previously concluded contract or may be executed as a separate document. This may be a commercial loan agreement, a borrower's receipt or another document (including a bill of exchange) certifying the lender's transfer of a certain amount of money to him, since the rules provided for the loan agreement apply to commercial loan relations, unless otherwise provided by the contract from which the corresponding obligation arose, and does not contradict the substance of such an obligation (part 2 of article 823 of the Civil Code of the Russian Federation).

The initial appearance of a bill in the market economy was already linked to the processing of a loan and interest on a loan. According to paragraph 4 of the Resolution of the Presidium of the High Council of the Russian Federation of 06.24.91. N 1451-1, organizations and entrepreneurs were allowed to "deliver products (perform work, provide services) on credit with interest charged to customers (consumers, customers) using bills of exchange for processing such transactions" [13]. Note that the bill should be issued a loan only in the form of a deferment of payment for goods. Soon such bills by the Letter of the Central Bank of September 9, 1991. No. 14-3 / 30 were called "commercial" [14], they were allowed to accept banks for accounting or as collateral as collateral for loans provided to customers, and in par. 2 p. 6 of the Decree of the President RF N No. 1662 [15] - "commodity", although such details are not provided by the bill legislation.

Today, a commercial loan can be provided in the form of bills of exchange. It is issued in the form of a bill of exchange (draft) issued by the seller, which is accepted by the buyer upon receipt of title documents or other documents (for example, warrant), or as a promissory note (solo) drawn up by the buyer.

Next, consider the ratio of the contract of commercial loan and the contract of account. The contract account is an agreement that reflects the agreement of the parties for a certain period of time not to demand payment under other business contracts between these same parties, but they enter these claims on account of each other, while the records of mutual debt are entered in a special book, on the left in the calendar order are recorded services rendered, goods sold, work performed, and on the right - received goods and services, work accepted. Then, after the expiration of the term specified in the contractual contract, the parties withdraw the balance, and this amount is paid or entered in the first line to the account of the next period. In the latter case, the contract account must either be automatically extended, if the appropriate condition is present in the original contract, or it must be concluded again. Since the contract agreement involves the postponement of payments, its legal nature is very similar to a commercial loan.

\section{Conclusion}

Summing up the study, it can be argued that a commercial loan contract is an accessory contract that is independent, but its independence is limited to the fate of the main contract.

Based on the analysis of similarities and differences in the deposit and advance payment, we can conclude that the deposit is always an advance, and since the advance condition is a condition for a commercial loan, the deposit condition is a condition for a commercial loan, but with specific features inherent advancement.

In confirmation of this position, we would also like to cite the position of M.F. Yermoshkina, who, in her research, singled out a new advancement function - the credit function, i.e. the deposit plays the role of a loan, and since the party to the contract in this case is not a credit institution, it is nothing more than a commercial loan. This approach to understanding the deposit determines the possibility of charging the amount of the deposit interest for the use of a commercial loan. "The economic basis for this conclusion is the fact that the deposit is transferred to the ownership of the recipient, who can dispose of it at his own discretion" [16].

Bill of exchange is one of the ways to execute a commercial loan agreement.

The ratio of the contract of commercial loan and the current account can be designated as follows:

- the similarity of the contract of contract and commercial loan is that

1) the contract of account and the contract of commercial loan are independent agreements,

2) both contracts provide for deferment of payment under civil law contracts, 
- the differences lie in the fact that both legal entities and individuals can be parties to both contracts, but in the contract account, only those engaged in entrepreneurial activity, and in the commercial loan contract there is no such limitation.

Based on the analysis, we can conclude that the contract account is one of the types of commercial loan contracts in the form of deferred payment. Thus confirms the fact that the contract of a commercial loan is an independent contract once again.

\section{References}

1. A. Bychkov, The intricacies of commercial credit. Ezh-Lawyer, 33. URL: http://base.garant.ru/57388001/ (2015). [in Rus.].

2. V. Mikryukov, Problem of regulation of commodity and commercial credit. Legislation and Economics, 11, 39-42 (2013). [in Rus.].

3. Gorbatov, K. Commercial credit in business relations. Corporate Lawyer, 7, 37-39 (2010). [in Rus.].

4. A. Burkova, Commercial credit. Lawyer, 9, 27-30 (2007). [in Rus.].

5. M.I. Braginsky, V.V. Vitryansky, Contract law. Contract loan, bank loan and factoring agreements. The contracts directed on creation of collective formations. URL: https://private-right.ru/wpcontent/uploads/Dogovornoe_pravo_T5-1.pdf (2006). [in Rus.].

6. L.-H. Chen, T.-W. Chiou, A fuzzy credit-rating approach for commercial loans: A taiwan case. Omega, 27(4), 407419. DOI: 10.1016/S0305-0483(98)00051-6 (1999).

7. Civil code of the Russian Federation (part one) from 30.11.1994 N 51-FZ. Retrieved from: http://www.consultant.ru/cons/cgi/online.cgi?base=LAW\&n=300822\&dst=4294967295\&cacheid=C8BC3E469B1852 262A4C20B4B8FC2762\&mode=rubr\&req=doc\&rnd=4154132ABB7C54282ECC90D38AD93FFE\#01207199827713 2168. Accessed: 26.12.2018 (1994). [in Rus.].

8. Civil code of the Russian Federation (part two) from 26.01.1996 N 14-FZ. Retrieved from: http://www.consultant.ru/cons/cgi/online.cgi?base=LAW\&n=300853\&dst=4294967295\&cacheid=3121AE6AFF68C7 4CD5E4D0F40B777FD4\&mode=rubr\&req=doc\&rnd=4154132ABB7C54282ECC90D38AD93FFE\#0225437441890 2736. Accessed: 26.12.2018 (1996). [in Rus.].

9. Federal Taxation Service of Russia, Order about Model guidelines for design, construction, reconstruction and overhaul of buildings and structures of the Federal tax service, its territorial bodies and organizations under the jurisdiction of the Federal from 09.04.2012 N MMB-7-10/230@/. Retrieved from: http://www.consultant.ru/cons/cgi/online.cgi?req=doc\&cacheid=5F64E186CA37A61979F54A1452D33D85\&SOR TTYPE $=0 \& B A S E N O D E=50 \& t s=117680341303487649484602926 \&$ base $=E X P \& n=682151 \& \mathrm{rnd}=4154132 \mathrm{ABB} 7 \mathrm{C}$ 54282ECC90D38AD93FFE\#035953622193974866. Accessed: 26.12.2018 (2013). [in Rus.].

10. B. Gongalo, The doctrine of ensuring the performance of obligations. Moscow: Statute (2002). [in Rus.].

11. O.A. Belyaeva, Legal nature of the deposit made for participation in the auction. Laws of Russia: Experience, Analysis, Practice, 12, 61-64 (2006). [in Rus.].

12. M.I. Braginsky, V.V. Vitryansky, Contract law. Book one: General provisions. Moscow: Statute. URL: https://private-right.ru/wp-content/uploads/Dogovornoe_pravo_T1.pdf (2001). [in Rus.].

13. Resolution of the Presidium of the High Council of the Russian Federation "On the application of the bill in economic circulation of the RSFSR" from 24.06.1991 N 1451-1. Retrieved from: http://www.consultant.ru/cons/cgi/online.cgi?req=doc\&cacheid=AB3DFDFBAC5FD1D1D7C4805428986B16\&SO RTTYPE=0\&BASENODE $=1 \&$ ts $=144991985207385083130005192 \&$ base $=$ LAW \&n=86\&rnd $=4154132 \mathrm{ABB}$ C542 82ECC90D38AD93FFE\#015370356021025477. Accessed: 26.12.2018 (1991). [in Rus.].

14. Central Bank of Russia, Letter about bank transactions with bills of exchange from 9.09.1991 N 14-3/30. Retrieved from:

http://www.consultant.ru/cons/cgi/online.cgi?req=doc\&cacheid=3FD537DCD02E67EDA69D91D8493E908D\&SO RTTYPE=0\&BASENODE $=1 \& \mathrm{ts}=4274038008936885137359927 \&$ base $=$ LAW $\& \mathrm{n}=2292 \& \mathrm{rnd}=4154132 \mathrm{ABB} 7 \mathrm{C} 542$ 82ECC90D38AD93FFE\#05668411913577402. Accessed: 26.12.2018 (1991). [in Rus.].

15. Decree of the President RF "On the improvement of settlements in the economy and increase of responsibility for their timely implementation" from $19.10 .1993 \quad \mathrm{~N}$ 1662. Retrieved from: http://www.consultant.ru/cons/cgi/online.cgi?req=doc\&cacheid=778C9B59918252E981ACAD9B6903D398\&SOR TTYPE $=0 \&$ BASENODE $=1 \&$ ts $=117680341303487649484602926 \&$ base $=$ LAW \&n=15535\&rnd $=4154132$ ABB 7 C 5 4282ECC90D38AD93FFE\#018862738051170314. Accessed: 26.12.2018 (1993). [in Rus.].

16. M.F. Yermoshkina, Deposit: Concept, legal qualification, separate types and scope of application. Moscow: Statute (2008) 